\title{
Practices of Secondary School Language Teachers in Conducting Action Research
}

\author{
Elias Admasu Tessema Tadesse \\ Madda Walabu University
}

\begin{abstract}
The main purpose of this study was to assess the Practices of Secondary School Language Teachers in Conducting Action Research. In order to achieve this objective, three instruments, namely, questionnaire, interview, and document analysis were used. While the questionnaires were used for teachers, semi-structured interview were done with school directors. Besides, document analysis was made with carefully prepared checklists.350 LanguageTeachers were selected using simple random sampling which was representative of total number. The researchers used both qualitatively and quantitatively methods of data analysis. While the close ended questionnaires were discussed using SPSS version 20, that is, with frequency, percentage, mean and standard deviation; the interview and document analysis were done through detail explanation and discussion with qualitative descriptive approach. The findings of the study depicted that there are inadequate involvement of teachers in conducting action research in the sample secondary schools. Moreover, it was indicated that there is little/no financial and material support on the part of the school to motivate teachers in doing research that enhance the teaching learning process. On the top of this, although the schools included conducting action research as part of their annual plan, there is no budget allocated for that purpose as well as scheme of acknowledging research work by giving some sort of incentives such as certificate, money, promotion, etc. for teachers. It was also identified through this study as there is skill gap, shortage of appropriate reference materials, heavy workload, lack of team spirit among teachers and less supportive environment to conduct action research. On the basis of the finding, it was recommended that teachers should get awareness on the role of action research, should be provided with appropriate and adequate training, integrating action research into teaching-learning process and motivating teachers using various techniques in order to increase their involvement in doing action research which in turn boosts the quality of education with reflective and innovative research outputs which can solve classroom related problems.
\end{abstract}

Keywords: Action research, Practice, Language Teachers, Secondary Schools

DOI: $10.7176 /$ RHSS/9-9-03

Publication date:May $31^{\text {st }} 2019$

\section{Introduction}

Background of the Study

Research is a systematic and organized effort to investigate a specific problem that needs a solution. It can also improve educational practices, teaching-learning process as well as advance knowledge and theory, that is, new ideas about how things can be done and why. Action research promotes a critical attitude, research into teaching, accountability, self-evaluation and professionalism. Stenhouse (1975) cited in Day (1999) indicates that in the long term improvement of education through the utilization of research and development on the creation of different expectations in the system will be generated only as schools come to see themselves as research and development institutions rather than clients of research and development agencies.

Research has been used to develop knowledge and solve perceived problems for a long period of time in history. Action research also in education has gained increasing attention in the past 20 years. It is viewed as a practical yet systematic research method that enables teachers to investigate their own teaching and their students' learning. As Tan et al (2009) stated traditionally, research in education intends to bring useful changes to either teachers' teaching or students' learning or both. Language teachers as teacher researchers often wish to carry out research within their classrooms or schools to improve their teaching, to assess a newly developed educational theory or to implement and evaluate an educational plan. According to McNiff and Whitehead (2006) action research has become increasingly popular around the world as a form of professional learning. It has been particularly well developed in education, specifically in teaching, and is now used widely across the professions. Action research can be appropriately integrated with education if teachers are able to conduct it at all levels and use the findings to solve practical problems.

As Chere (2003) stated like the other disciplines, language teaching classrooms, in general, become attractive areas of research interest among many educators - more specifically among language teachers who are at the heart of the profession. In other words, classroom-based research works which can be possibly carried out by classroom teachers themselves can be of help to teachers to examine all the strengths and weaknesses of their teaching linked with the teaching of languages. Moreover, action research can assist teachers to be collaborators in dealing with the hindrances as much as they can. Action research is used to address real world problems, with 
the researcher becoming actively involved in the research process as a change agent. According to FDRE Education and training policy (1994) research of practical societal impact will be given priority and the necessary steps will also be taken to facilitate the coordinated efforts of all those concerned. Although there are research work efforts related to continuous assessment, active learning, action research, CPD in primary schools, but there are negligible effort around secondary schools in solving some educational problems through action research as some research findings indicate (Chere, 2003; Teshome, 2006).

Thus, here the researchers want to Explore the Practices of Secondary School Language Teachers in Conducting Action Research. Because the more the teachers take part in doing action research the better they improve their teaching-learning conditions as well as enhance their professional career too.

\section{Statement of the Problem}

Action research can be a powerful and liberating form of professional enquiry because it means that practitioners themselves investigate their own practice as they find ways of living more fully in the direction of their educational values. They are not told what to do. They decide for themselves what to do, in negotiation with others. This can work in relation to individual and also collective enquiries. More and more groups of practitioners are getting together to investigate their collective work and put their stories of learning into the public domain (McNiff and Whitehead, 2006).

Obviously, teachers are expected to conduct action research, but doing action research requires adequate knowledge and skills that are to be acquired through training and regular practice. Conducting action research is challenging because the researcher not only conducts research but simultaneously enacts change in implementing an intervention.

Ethiopian government is also focuses on continued improvement of quality teaching and learning through targeted interventions which bring about lasting systemic change. In order to improve schools teachers have to be supported by adequate training on action research. In Ethiopia, however, the works of Seyoum (1998), Adane (2000), Yalew (2000) and Teshome (2006) are a few of local research inputs which show the involvement of teachers. But still a lot is expected from teachers to make the teaching-learning process more effective and efficient through the work of research.

Hence, the present research targeted to fill the gap related to the practices of secondary school language teachers in conducting action research.

\section{Objectives of the Study}

The main objective of this study is to investigate the major practices of secondary school language teachers in conducting action research. In order to elicit the required information the following specific objectives are considered:

1. To identify attitude of secondary school language teachers in carrying out action research that enhances their professional competence.

2. To find out the extent to which action research findings are used in supplementing thecurriculum, improving teaching-learning process and solving educational problems.

3. To analysis the major factors that related to hindering the practices of secondary school language teachers in doing action research.

4. To assess the focus of research conducted by secondary school language teachers and explore the strengths and weaknesses of research procedures adapted by them.

5. To suggest some important actions to be taken by the concerned bodies in order to enhance the participation of secondary school language teachers in doing action research.

\section{Significance of the study}

These days Ethiopian government gives due attention for quality of education. This quality of education comes when teachers are active participant in conducting action research in order to solve barriers of teaching-learning processes in language classes. Accordingly, the result of this study is believed to be useful in the following aspects.

- Provide valuable information to decision makers, curriculum developers, supervisors, secondary school language teachers, promotion committees, policy makers who are concerned with the quality of language teachers in secondary schools.

- Assist secondary school language teachers in identifying the major hindrances to conduct action research and to take remedial action. Besides, various stakeholders who are involved in the training and preparation of secondary school language teachers obtain information for improvement and development of appropriate training programme on enhancing the capacity of doing action research.

- Raise awareness of secondary school language teachers on how to apply effectively and efficiently action research in their schools on problems that need immediate action. Moreover, it might help MOE, 
Oromia Education Bureau, Universities and design available strategy, which can promote the implementation of action research in the secondary school.

- Finally, motivate other researchers to use it as springboard in order to conduct action researches in the subjects they have been teaching.

\section{Research Design and Methodology}

The study attempts to describe the practices of secondary school language teachers in doing action research in three selected zones of Oromia Regional State. A descriptive survey design was used so as to assess the practices of secondary school language teachers in conducting action research. The design was selected on the assumption that it is helpful to gather enough information from many language teachers on the issues of study. The Appropriateness of this design for such study was noted by many scholars. For example, Koul (1996) states that descriptive survey design becomes useful particularly where one needs to understand some particular information. Best and Khan (1989) have noted that a descriptive survey research design involves a clearly defined problem and definite objectives.

The researchers used mixed approach where data from the quantitative and qualitative complemented each other. As part of the quantitative design the survey method was used to assess secondary school language teachers' practices in conducting action research. The quantitative data was complemented by qualitative data obtained from interviews and analysis of documents.

Thus, in this part the description of study area sample size, sampling techniques, instrument of data collection, the procedures and methods of data analysis were presented one after the other.

\section{Description of Study Area}

This study was conducted to describe the practices of secondary school language teachers in doing action research in three selected zones of Oromia Regional State. Thestudy focused on three zones that is Bale, West Arsi and Arsi zones.

\section{Sample Size}

As it is quite difficult to include all the zones in Oromia Regional State in the study, only three administrative zones were considered using purposive sampling method. The rationale for selecting these zones is from the point of proximity and the zones are Catchments by Madda Walabu University. In addition, the researchers want to maintain confidence level of $95 \%$ (which means a margin of error/error tolerance of 0.05 ). To make it clear, as to Dornyei (2007) confidence interval ranges between 0 and 1 , therefore $1-0.95$ is equals to 0.05 which is confidence interval (margin of error).Regarding the total population, there are 2968 Language teachers in the three Zones and 352 of them were selected using simple random sampling using Yemane (1967) formula as follows:

$$
\mathbf{n}=\frac{\mathbf{N}}{1+\mathbf{N e}^{2}}
$$

Where, $\quad \mathbf{n}=$ Number of samples (sample size), $\quad \mathbf{N}=$ Total population and $\mathrm{e}=$ Error tolerance. So, when we calculate the sample size using the above formula:

$$
n=\underline{29682968}=352(\text { Sample size }) 1+2968 * 0.05^{2}=1+2968 * 0.0025=1+7.42=
$$

Therefore, 352 Language teachers were randomly selected from the total population of 2968 from thirty three (33) secondary schools of the three zones under the study. Furthermore, 33 school principals of all the selected schools were included in the study.

\section{Instruments used in the Study}

The researchers utilized three instruments to obtain reliable and rich data from various sources using different techniques which were employed in this study. These were questionnaire, interview and document analysis.

Questionnaire-Both open-ended and close ended questionnaires were prepared to elicit the required information from teachers and school administrators. As it is a survey research the questionnaires assisted the researchers to gather ample data from large number of participants within a short period of times. Besides, the respondents also freely expressed their idea through writing which the researchers could easily utilize to achieve the objectives of the research work under investigation.

On the bases of this, 350 (Three hundred fifty) teachers filled the questionnaire who were taken from 33(thirtythree) sample schools. The researchers included representative numbers of teachers from each school.

Interview-The use of interview as data collection instrument permits a level of in-depth information, free response and flexibility that may not be obtained by other means. The researchers of this paper also firmly 
believed that it was reasonable to have the careful consideration of respondents' views. Taking this into account, qualitative data will be collected via detailed interview from the subjects of the study.

Thus, semi-structured interview used to elicit detail information from teachers and school principals in a face to face situation. 33(thirty three) participants are included in the interview. While school principals will be taken in a comprehensive sampling, teachers can be considered in a systematic sampling method.

Document Analysis-The researchers will also try to examine various documents in the sample school which is related to conducting research to solve the school immediate problems related to teaching-learning process. The data to be collected through the remaining two instruments can be supported with this tool as well. Documents like continuous professional development (CPD), promotion document, action research work, etc. are the major focus area for analysis.

\section{Methods of Data Analysis}

In data analysis the researchers used both quantitative and qualitative methods. Dornyei (2007) emphasised using mixed approach has the advantages of increasing the strength of the research work, improving the validity, allowing multi-level analysis of complex classroom issues and the final results are applicable to large audience than those of a mono method study. Moreover, the mixed method is used to obtain information concerning the current status of the phenomena and to draw conclusions from the facts discovered.

The quantitative data obtained through the questionnaires was analyzed by using SPSS version 20, frequencies, percentages, mean value and standard deviation. Qualitative data obtained through interviews with the School Directors were analyses qualitatively.

Finally, conclusion and recommendations will be given based on the findings obtained from the research work.

\section{Results and Discussion}

\section{Background Information about Participants}

The first part of teachers' questionnaire consists of some major points which can help the readers to get appropriate information about the subjects. This deals with sex, zone, qualification, service year and work load per week. Before discussing the data related to the major questions, a summary of characteristics of the subjects is presented here.

Table 1 Background Information about Participants

\begin{tabular}{|c|c|c|c|c|c|c|c|c|c|c|c|c|c|c|c|c|c|}
\hline \multirow[t]{2}{*}{ No } & \multirow{2}{*}{\multicolumn{2}{|c|}{$\begin{array}{l}\text { Respondents } \\
\text { Zone }\end{array}$}} & \multicolumn{3}{|c|}{ Sex } & \multicolumn{3}{|c|}{ Qualification } & \multicolumn{5}{|c|}{ Service Year } & \multicolumn{4}{|c|}{ Work Load } \\
\hline & & & $\mathrm{M}$ & $\mathrm{F}$ & $\mathrm{T}$ & $\mathrm{Di}$ & $\mathrm{BA}$ & MA & $\stackrel{n}{1}$ & $\frac{0}{b}$ & $\stackrel{n}{I}$ & ָ̊ & 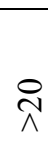 & $\stackrel{0}{1}$ & $\stackrel{n}{ \pm}$ & ণ্ণ & $\stackrel{\overbrace{}}{\wedge}$ \\
\hline 1 & Bale & 120 & 89 & 31 & 120 & 1 & 116 & 3 & 2 & 6 & 11 & 50 & 51 & 5 & 19 & 72 & 24 \\
\hline 2 & Arsi & 115 & 84 & 31 & 115 & 1 & 113 & 1 & 2 & 5 & 9 & 51 & 48 & 2 & 19 & 72 & 22 \\
\hline 3 & West Arsi & 115 & 84 & 31 & 115 & 1 & 113 & 1 & 2 & 5 & 9 & 51 & 48 & 2 & 19 & 72 & 22 \\
\hline
\end{tabular}

Regarding to Qualification from all samples 3 Respondents has Diploma, 344 have Bachelor degree and 3 of them have MA. The intended information for this study was gathered from two groups; namely, language teachers and Directors of schools in three Administrative zones (Bale, Arsi and W/Arsi). A total of 383 respondents were included in the study. 350 of them are teachers and 33 of them are directors. Regarding to zone of respondents from Bale zone 120, and From Arsi and W/Arsi 115 language teachers were selected from each.

Table 2 Work load of Participants per week

\begin{tabular}{|c|l|c|l|l|}
\hline work load per week & Frequency & Percent & Mean & Sta. Deviation \\
\hline $1-10 \mathrm{chr}$ & 9 & 2.6 & 2.9857 & 67905 \\
$11-15 \mathrm{chr}$ & 56 & 16.0 & & \\
$16-20 \mathrm{chr}$ & 216 & 61.7 & & \\
above 20 & 69 & 19.7 & & \\
Total & 350 & 100.0 & & \\
\hline
\end{tabular}

As mention in the above table, for the sake of discussion, the work load of language teachers has five categories: 1 to $10 \mathrm{crhs}, 11$ to $15 \mathrm{crhs}, 16$ to $20 \mathrm{crhs}$, and above twenty crhs. With frequencies and percentages of $9(2.6 \%), 56(16 \%), 216(61.7 \%)$, and $69(19.7 \%)$, samples, respectively. From this data Most of the respondents has from 16 to 20 credit hours per week, and above 20 credit hours are 94 or $26.9 \%$ ), so they were very busy to conduct action research. 


\section{Analysis of Teachers Questionnaire}

Close Ended Questionnaire

Table 3 Practices and attitudes of language teachers towards conducting action research

\begin{tabular}{|c|c|c|c|c|c|c|}
\hline & Item & & Frequency & Percent & Mean & Sta. .Deviation \\
\hline \multirow[t]{3}{*}{1} & \multirow{3}{*}{$\begin{array}{l}\text { Have you ever been involved in any kinds of } \\
\text { research? }\end{array}$} & Yes & 293 & 83.7 & \multirow[t]{3}{*}{1.1629} & \multirow[t]{3}{*}{.36976} \\
\hline & & No & 57 & 16.3 & & \\
\hline & & Total & 350 & 100.0 & & \\
\hline \multirow[t]{3}{*}{2} & \multirow{3}{*}{$\begin{array}{l}\text { Have you ever conducted action research in } \\
\text { teaching Amharic, Afan Oromo or English } \\
\text { Languages? }\end{array}$} & yes & 70 & 20.0 & \multirow{3}{*}{1.8000} & \multirow{3}{*}{.40057} \\
\hline & & No & 280 & 80.0 & & \\
\hline & & Total & 350 & 100.0 & & \\
\hline \multirow[t]{3}{*}{3} & \multirow{3}{*}{$\begin{array}{l}\text { Does conducting action research in school has } \\
\text { advantage to promotion? }\end{array}$} & yes & 350 & 100.0 & \multirow[t]{3}{*}{1.0000} & \multirow[t]{3}{*}{.00000} \\
\hline & & No & - & - & & \\
\hline & & Total & 350 & & & \\
\hline \multirow[t]{3}{*}{4} & \multirow{3}{*}{$\begin{array}{l}\text { If conducting Action research has advantage } \\
\text { have you tried in your subject? }\end{array}$} & yes & 60 & 17.1 & \multirow[t]{3}{*}{1.8286} & \multirow[t]{3}{*}{.37742} \\
\hline & & No & 290 & 82.9 & & \\
\hline & & Total & 350 & 100.0 & & \\
\hline \multirow{3}{*}{5.} & \multirow{3}{*}{$\begin{array}{l}\text { Have you conducted action research in } \\
\text { Teaching Languages for the enhances your } \\
\text { professional competence? }\end{array}$} & yes & 60 & 17.1 & \multirow[t]{3}{*}{1.8286} & \multirow[t]{3}{*}{.37742} \\
\hline & & No & 290 & 82.9 & & \\
\hline & & Total & 350 & 100.0 & & \\
\hline
\end{tabular}

Table 3 gives detailed information concerning the respondents' Practices and attitudes, of language teachers in conducting Action research in language teaching. Accordingly, the samples were asked whether or not they carried out any kind of research and action research in teaching their Subject in the questionnaire Items 1 and 2 , respectively. As a result, 293 or 84 per cent and 70 or 20 per cent of the samples said that they participated in some kind of research in language action research, respectively. But, the remaining 57 or 16.3 per cent and 280 or 80 per cent of the samples responded that they were not involved in any kind of research and action research, respectively.

Regarding to Item 3 all respondent or $350(100 \%)$ of them are understand about advantage of action research in the school. But due to different reasons they do not practiced. Item 4 and Item 5 raised to respondent "If conducting Action research has advantage in their subject?" the answer of the respondent for two items are 60(17.1\%) said yes, 290(82.9) are said that they gave much emphasis to teaching than to research.

Table 4 Constraints to conduct Action research

\begin{tabular}{|c|c|c|c|c|c|c|}
\hline & Item & & Frequency & Percent & Mean & Sta .Deviation \\
\hline \multirow[t]{2}{*}{6} & \multirow[t]{2}{*}{ Shortage of time } & Yes & 278 & 79.4 & \multirow[b]{2}{*}{1.2057} & \multirow[b]{2}{*}{.40480} \\
\hline & & No & 72 & 20.6 & & \\
\hline \multirow[t]{2}{*}{7} & \multirow[t]{2}{*}{ Problems of budget } & Yes & 330 & 94.3 & \multirow[b]{2}{*}{1.0571} & \multirow[b]{2}{*}{.23245} \\
\hline & & No & 20 & 5.7 & & \\
\hline \multirow[t]{2}{*}{8} & \multirow{2}{*}{$\begin{array}{l}\text { Undermining the role of action } \\
\text { research }\end{array}$} & Yes & 178 & 50.9 & \multirow[b]{2}{*}{1.4914} & \multirow[b]{2}{*}{.50064} \\
\hline & & No & 172 & 49.1 & & \\
\hline \multirow[t]{2}{*}{9} & \multirow{2}{*}{$\begin{array}{l}\text { Lack of enough of action research } \\
\text { skills }\end{array}$} & Yes & 163 & 46.6 & \multirow[b]{2}{*}{1.5343} & \multirow[b]{2}{*}{.49954} \\
\hline & & No & 187 & 53.4 & & \\
\hline
\end{tabular}

The research constraints reported above is done by frequencies and percent that each constraint is shortage of time to conduct action research 278 (79.4\%) respondents said yes and No 72(20.6\%), regarding to Problems related with budget 330(94.3\%) respondents said yes and 20(5.7\%) respondents said no. referring to the information given in the above table, undermining the role of research, 178(50.9\%) said yes and 172(49.1\%) said is no, lack of enough research skills, $163(46.6 \%)$ said yes and $187(53.4 \%)$ respondent said no.

From the above tables we understand that shortage of time, Problems related to Budget, undermining the role of research and lack of enough research skills were serious research constraints reported in secondary school. 
Table 5 Points related to Teachers knowledge and School Environment in Conducting Action Research

\begin{tabular}{|c|c|c|c|c|c|c|}
\hline No & Items & \multicolumn{2}{|c|}{ Frequency } & Percent & Mean & Sta. - \\
\hline \multirow[t]{2}{*}{10} & \multirow{2}{*}{$\begin{array}{l}\text { Do you feel confidence in your research skills as a } \\
\text { language teacher? }\end{array}$} & Yes & 282 & 80.6 & \multirow[b]{2}{*}{1.1943} & \multirow[b]{2}{*}{.39622} \\
\hline & & No & 68 & 19.4 & & \\
\hline \multirow[t]{2}{*}{11} & \multirow{2}{*}{$\begin{array}{l}\text { Lack of enough language teaching research courses } \\
\text { offered }\end{array}$} & Yes & 250 & 71.4 & \multirow[b]{2}{*}{1.2857} & \multirow[b]{2}{*}{45240} \\
\hline & & No & 100 & 28.6 & & \\
\hline \multirow[t]{2}{*}{12} & \multirow{2}{*}{$\begin{array}{l}\text { Lack of updated research materials in language } \\
\text { teaching }\end{array}$} & Yes & 270 & 77.1 & \multirow[b]{2}{*}{1.2857} & \multirow[b]{2}{*}{.45340} \\
\hline & & No & 80 & 22.9 & & \\
\hline \multirow[t]{2}{*}{13} & \multirow[t]{2}{*}{ Absence of training on how to conduct action research } & Yes & 318 & 90.9 & \multirow[t]{2}{*}{1.0914} & \multirow[t]{2}{*}{.28863} \\
\hline & & No & 32 & 9.1 & & \\
\hline \multirow[t]{2}{*}{14} & \multirow[t]{2}{*}{ Lack of conducive environment in the school } & Yes & 90 & 25.7 & \multirow[t]{2}{*}{1.7429} & \multirow[t]{2}{*}{.43768} \\
\hline & & No & 260 & 74.3 & & \\
\hline \multirow[t]{2}{*}{15} & \multirow[t]{2}{*}{ Lack of encouragement from school } & Yes & 288 & 82.3 & \multirow[b]{2}{*}{1.1771} & \multirow[t]{2}{*}{.38234} \\
\hline & & No & 62 & 17.7 & & \\
\hline \multirow[t]{2}{*}{16} & \multirow[t]{2}{*}{ Lack of research interest in School } & Yes & 95 & 27.1 & \multirow[t]{2}{*}{1.7286} & \multirow[t]{2}{*}{.44533} \\
\hline & & No & 255 & 72.9 & & \\
\hline \multirow[t]{2}{*}{17} & \multirow[t]{2}{*}{ Absence of collaboration among colleagues in School } & Yes & 225 & 64.3 & \multirow[t]{2}{*}{1.3571} & \multirow[t]{2}{*}{.47984} \\
\hline & & No & 125 & 35.7 & & \\
\hline \multirow[b]{2}{*}{18} & \multirow[t]{2}{*}{ Heavy workload } & yes & 284 & 81.1 & \multirow[t]{2}{*}{1.1886} & .39173 \\
\hline & & No & 66 & 18.9 & & \\
\hline
\end{tabular}

Regarding research skills (Item 10), only few of the samples 68 (19.4\%) reported that they feel confident in their research skills whereas many of therespondents $282(80 \%)$ responded to the negative. the respondents' responses seemed to show consistency because it was only 6 of the samples (18.2 per cent) who reported that they had clear information on (collecting data, analyzing data, interpreting data...) their research skills how to undertake teacher-research when a majority of the samples ( 27 or 81.8 per cent) reported that they had not.

Table 6 Respondents experience related to action research.

\begin{tabular}{|c|c|c|c|c|}
\hline & Item & & Frequency & Percent \\
\hline \multirow[b]{2}{*}{19} & \multirow{2}{*}{$\begin{array}{l}\text { Have you taken relevant research courses which are pertinent language } \\
\text { teaching during your college or university training years or pre-service } \\
\text { training? }\end{array}$} & yes & 98 & 28.0 \\
\hline & & No & 252 & 72.0 \\
\hline \multirow[t]{2}{*}{20} & \multirow{2}{*}{$\begin{array}{l}\text { The courses that you taken are adequate to enable you to carry out } \\
\text { language teaching action research? }\end{array}$} & ye & 59 & 16.9 \\
\hline & & No & 291 & 83.1 \\
\hline \multirow[t]{2}{*}{21} & \multirow{2}{*}{$\begin{array}{l}\text { Do you regularly read different books, journals and articles on language } \\
\text { teaching research? }\end{array}$} & ye & 88 & 25.1 \\
\hline & & & 262 & 74.9 \\
\hline \multirow[t]{2}{*}{22} & \multirow{2}{*}{$\begin{array}{l}\text { Do you have clear information on your research skills on how to do } \\
\text { language teaching action research? }\end{array}$} & yes & 69 & 19.7 \\
\hline & & $\mathrm{N}$ & 281 & 80.3 \\
\hline \multirow[t]{2}{*}{23} & \multirow{2}{*}{$\begin{array}{l}\text { Does language Teachers in your school collaborate with one another } \\
\text { to carry out action research? }\end{array}$} & yes & 43 & 12.3 \\
\hline & & No & 307 & 87.7 \\
\hline
\end{tabular}

Regarding to experience related to action research Item number 19, 20, 21, 22 and 23 are prepared. For responding Item 19 98(28.0\%)said yes and 252(72\%) respondents said no. this shows language teachers duringcollege or university training years or pre-service training absence of research courses. starting from this response for Item 20 291(83.1\%)are said The courses that they taken are not adequate to enable you to carry out action research.

Concerning the reading habit of language teachers (Item 21$), 88(25.1 \%)$ of the samples said that they read different books, articles, journals and some others nevertheless, $262(74.9 \%)$ of them replied that they did not read such materials. The major reason reported by the respondents was the scarcity of relevant reading materials on language teaching research issues. This result seems to contradict with Law and Glover (1996) who argued that professional development should be continuous.

Finally, the samples were asked whether or not they carried out action research collaboratively (Item 23). Few of them 43(12.3\%) responded that they did collaborate with one another when they undertook action research. However, 307(70.7\%) said that they were involved in action research individually, not collaboratively. In fact, this approach of research undertaking seemsto be criticized; hence, it seems to lack the spirit of sharing of ideas (Webb, 1996).

The second part of the Questioners; Itemland 2 checking the believe of respondents toward Action research. For these items 100 (28.6\%) respondents said agree and 250(71.4) said strongly agree. To item 2 43(12.3) respondents said Disagree, 255(72.9) said agree and 52(14.9) said strongly agree. From point of view most of respondents believe that teachers' decision should be supported by action research and language teaching is 
problematic and needs classroom-oriented investigations. but some respondent do not believe on the raised idea. Because on item 2 they said disagree.

Regarding to Item 3 and 4 asking about agreement of respondent on the School where they work, action research is less understood in the teaching of language and lack of support from school directors is one source of the problem which does not allow me to do action research. These sentences are the counter check of constraints of action research in language teaching in the school. According to the respondents for item 3, 280 $(81.3 \%)$ said agree and 28 (the respondents said $28(8 \%)$ said strongly agree but $41(11 \%)$ said disagree .from this Pont of view School where the respondents work, action research is less understood in the teaching of language they may need training how they conduct action research. This point also mentioned under constraints of action research. In contrary, limited number of respondents indicated as the School where they work, action research is understood in the teaching of language.

Concerning to Item 4 lack of support from school directors is one source of the problem which does not allow me to do action research $255(72.9 \%)$ respondents said agree and 51(14.6\%) respondents said strongly agree. So the school directors do not support the language teachers in this aspect. In terms of Sentence 5,6,7,8,9 and 10 they are Items of crosschecks to the previous question regarding to constraints of Action research. Most of the respondents confirmed what they mentioned before.

\section{Open EndedQuestionnaire}

In this part of analysis an attempt has been done to discuss the questions raised for teachers in the open-ended part by triangulating with directors interview and document analysis.

Besides, the above close ended questions the following reflection questions were included in teachers' questionnaire. Accordingly, teachers were answered the first item, what do you think about the existing relationship between teaching and research?More or less in a similar way. The respondents stated that as there are strong relationship between teaching and research, since the finding of the research improved the situation from time to time. The respondents also added as research gives solution to educational problem in a scientific way as well as enhances quality of education.

The subjects of the study pointed out as teaching and research create awareness on teaching methods, improve knowledge and skills of teachers, increase their professional commitment and critical thinking on what they do; although they participate rarely in carrying out the activity. These responses tell the researchers as the respondent teachers have good knowledge on the relationship between teaching and research.

The second item deals with the existing relationship between Language teaching and action research. Almost all of the teachers stated as action research improve the practice of teaching, give immediate solution for classroom problems; make teachers competent and effective in their teaching profession. The interviewed school directors also confirmed the same ideas as research supports teaching-learning process and they have very close relationship. Besides, the review of related literature part also indicated similar thing what the researchers identified through this study. It is advisable and beneficial to support the teaching-learning process with action research in order to assist our students to be problem-solver and autonomous in their study.

The third open-ended item of teachers was designed to elicit about their practical involvementin doing action research. In this regard, the majority of the teachers explained as there is very little involvement because of the following major points.

Heavy teaching load ,Lack of appropriate procedures on how to do action research, Shortage of time because additional responsibilities like homeroom teacher, unit leader, club coordinator, and other various school committee member Item four was formulated to get information about teachers' belief regarding the role of action research in Language teaching. Teachers' respondents identified the following points:

To get solution for language teaching, to improve our work/teaching-learning process, to up-date- methods of teaching from time to time, essential to do our work effectively, communicate with many people and their classroom activities; help us to be good facilitator of the teaching-learning process, being successful in our professional career

The above points clearly showed that teachers have positive attitude and belief as action research has great role in improving the practice of teaching and actual classroom situations.

Teachers also discussed in detail in item five about the most revealing problems or research constraints which they have encountered in carrying out Language teaching action research. They have included the following points in their list. These are: Shortage of time to conduct action research, Lack of budget/materials (Money, computer, stationery support),Lack of interest (No motivating situation in some schools), Shortage of reference materials (books, e-books, internet access, journals, etc),Lack of appropriate support from school/ district/ zone educational office, Lack of giving practical attention/ emphasis, Lack of incentives ( money, material, certificate, acknowledgement, etc).The points listed above are common for the majority of the respondents although there are very little attempt of support in a few schools by providing them with writing materials and verbal motivation. 
On the other hand, the final item was prepared to identify what techniques the respondents suggest to get involved more Language teachers in undertaking action research. They have indicated providing various training, incentives, reducing work load, involving all stakeholders, motivating, providing with materials, moral and other supports as much as possible.

\section{Analysis of Interview Responses}

Taking this into account the researchers interviewed 33 Secondary School Teachers in a face-to-face situation with the help of semi-structured guidelines.

For item 1 which deals the role of director in the school, the majority of them indicated as they are: Leading both the academic and administrative issues, Planning and coordinating major school activities, Working with all stakeholders of schools, Evaluating the strength and weakness of the whole school activities, Supporting and checking the application of teaching-learning process and research activities together with vice directors.

Some of the interviewed directors also mentioned as they work on Continuous Professional Development (CPD), School Improvement Programme (SIP), Information Communication Technology (ICT), Ethical Education and other related areas.

On the other hand, whether the school have a specific timetable for conducting action research, almost all of them explained as they include in their annual plan of the school. They have stated as teachers are expected to do action research as part of their professional career and semester based performance evaluation. The interviewed school directors also added as they give direction to teachers to conduct research at least in team. The other question on which teachers gave us their opinions were on item 3 if the school have enough annual budgets for doing research. Regarding this question all of the interviewed teachers responded as they do not have any budget for doing research. A few of them indicated that they provide the teachers rarely with paper and pen. Apart from these, teachers are expected to conduct action research in a group/team based on their subjects for Performance Evaluation of each semester and their Continuous Professional Development (CPD). The participants of this interview also added that as there is no incentive and less value is given on performance evaluation; the majority of them do not pay attention for carrying out action research in their schools. The schools' annual plan also indicated as there is no budget allocated for research purpose. Furthermore, the respondents also indicated as the teachers are likely to spend their time on other issues (building fence, gardening, tutorial class, participating in pedagogical centre, supporting director/vice directors with routine activities, etc) which they assume to get good value with the eyes of their director and vice directors.

Item 4 of the interview was designed to check whether school directors give recognition to teachers'research. The majority of theinterviewed directors confirmed that they motivate teachers' in order to conduct research on any of classroom problems. In some case there are a few schools which give them stationery support to encourage teachers' participation. As doing research is one of the activities of teachers there is other style of giving different recognition scheme. In rare cases there is time where the results of the research communicated to the concerned staff members. Almost all of them indicated as there is no/ very littlebudget allocated to do research in secondary schools. Open-ended part of teachers questionnaires also showed similar result as there is no emphasis on doing research both on the part of school and teachers too.

Regarding item 5, whether there is a conducive atmosphere in their schools to do action research in terms of resources and materials; greater than two third of them stated as there are favourable condition in order to conduct research specially moral support. But there is no/little support in terms of resources and materials for this purpose. Teachers also confirmed the same ideas in their questionnaire. Besides, the researchers also crosschecked the issue during their stay in the sample schools through informal discussion with teachers. On the other hand, item 6 focuses on point whether their schools teachers gain training on Language teaching research issues. A few of them from each Zone addressed as there are training from college instructors on other topics not directly on action research. They also commented as they need continuous training to fill the skill gaps of teachers in doingresearch as much as possible. The interview directors also noted that as Madda Walabu University should play its role in equipping teachers with necessary knowledge and skills.

The final item of interview was designed toidentify Language teachers involvement in conducting action research compared to other departments in the same school. As the majority of the respondents asserted there are similar trend among all school teachers in relation to their participation. In a few places where there is research, Language teachers are better than other subject teachers. The researchers' also identified similar things during document analysis as a few of action research work found in the schools were conducted by Language teachers. In general, from the discussion so far made by triangulating the data gathered through questionnaire, interview and various documents depicted as only a few teachers took part in doing action research.

\section{Analysis of Data from Various Documents}

The researchers also analysed data collected from various documents such as Annual Plan of the School, Action Research done in the School, Teachers Continuous Professional Development (CPD) documents, Teachers 
Performance Evaluation Format, etc. Fromthe above various documents the researchers examine very carefully the practices of Language teachers in doing action research in their respective schools.

In all the sample school there are annual plan attached/fixed on the wall in director's office. In the annual plan under the list of activities there is conducting action research on various topics. But as the researchers already checked through interview and questionnaire there is no budget allocated to carry out the activity of research. The document analysis part also indicates the same thing as there is no budget that school uses to assist teachers who participated in doing research.

The researchers also examined the performance evaluation format of teachers that school use to assess teachers every semester. In this format there is one question that asks whether teachers conduct research or not. The question bears from 4-5 marks only. As a result most of the directors indicated as teachers do not give much attention for doing action research for that small amount of points in evaluation; instead they shit to doing other activities in which they may get more marks.

$\{\{$ Furthermore, the action research done in the sample schools are very few in number. The CPD documents that the researchers examined also approved the same thing. There are a few research works on topics related to students drop out, the cause of late comer students, misbehaviour ofstudents, implementation of continuous assessment, cheating on examination, etc. which is not directly related to language teaching. Besides, the majority of them do not follow appropriate procedures of conducting action research. On the other hand, whatever the topic of the research deals with, the participation of language teachers are by far better than the other subject teachers.

Researchers' document analysis as a whole asserts that the actual involvement of language teachers in doing action research is insignificant. This was also supported by triangulating the data collected through the three tools used in this study.

\section{Major Findings of the Study}

In this section, the major findings of the study have been drawn based on analysis and discussions made earlier. The finding indicated that as action research supports and improves the classroom teaching-learning process although there is little/no involvement on the part of language teachers in conducting action research in the sample schools. It is also understood from the finding that there is skill gap in applying appropriate procedures to do action research by teachers. For this reason teachers are not confident and competent enough to carry out action research on classroom problems. The results of the study asserted that there is experience difference and gap in time of training in pre-service which makes teachers different from one another. The finding of the study also indicated that there are certain hindrances to do research; such as shortage of time, heavy work load, lack of cooperation among teachers, less support from school and other concerned bodies, absence of incentives, etc. The finding of the study showed that the existing a few research works cannot directly related to language teaching and learning process; instead it is more of administration and management problems.

\section{Conclusion}

Conclusions have been drawn from the findings and discussions mainly based on the acquired data sources. Besides, both quantitative and qualitative research design have been taken into account in drawing conclusions.

Majority of the respondents of the study confirmed that the importance of action research in educational settings. Thus, it could be concluded thatactive involvement of teachers in carrying out action research plays a significant role in solving immediate problems of classroom situations. This study has also come up with the conclusion that there is a skill gap in doing action research by using appropriate procedures on the part of the teachers. In line with this, it is believed that providing short term training, workshop and awareness creation intervention programme to assist teachers in this regard.

The findings indicated that there are a number of obstacles to do action research. Hence, it is concluded that all the stakeholders expected to perform their own role as much as they can in order to minimize the problems. The finding of the study also identified that there is lack of cooperation among teachers and support from school management bodies and other hierarchical ladder which works on education. Thus, it can be summed as team work/spirit and assistance of school directors boosts the activity of action research. The results of the study also confirmed thatthe majority of existing action research work cannot directly in line with language teaching and learning process. They focus on points that can be easily solved through discussion with school administrators. Cases like late comer students, misbehavior in classroom, cheating on examination and other similar points can easily solved through face-to-face discussion. This study has come up with the potential and practical importance of the practices of secondary school language teachers in conducting action research. The following points are recommended:

There is no doubt that research supports the classroom teaching with the help of scientific outputs. In order to do this interest and motivation to do the activities are mandatory. Thus, it is recommended that the school and other concerned bodies should motivate teachers using various techniques or by providing them incentives in the 
form of money, certificate, etc to increase their participation. Since action research solves immediate classroom problems with cooperative effort of similar subject teachers, it is advisable that curriculum designer or textbook writers should integrate action research into teaching-learning process which in turn assists students' effective learning and develops teachers' confidence. The findings of the study also indicated as teachers have variation in experiences and the methodology they trained with. Therefore, it is recommended to give appropriate, timely and adequate training for teachers on how to conduct research in general and action research in particular. The results of the study also addressed the importance of action research in educational setting.

Hence, it should be appropriate to create awareness on the role of action research since it provides teachers with the technical skills and specialized knowledge required to develop positive change within classrooms, schools, and communities. The findings of the study also identified the major hindrances in doing action at school level. Thus, it is recommended that the school, district education bureau, and other concerned bodies should take part in all aspects in order to maintain the quality of education as much as possible. The findings of the study also asserted as the existing action research work related to some administrative issues instead of directly focusing on the subject matter. Therefore, it is recommended to assist teachers to give due emphasis for topics related to language skills and sub skills to improve the actual classroom situations with up-to-date teaching methodology and techniques.

\section{References}

Best, J.W. And Kahn, J.U. (1989)Research In Education. New Jersey: Prentice Hall.

Burns, R.B. (2000) Introduction To Research Methods, 4th Ed, London: Sage Publications.

Calhoun, E. (2001)Action Research For School Improvement. Educational Leadership. 59(6), 18-24.

Cherie Mesfen,(2003) An Exploration In To The Involvement Of Elt Teachers In Action Research: The Case of three Teachers Training Colleges. A Thesis Submitted To School Of Graduate Studies Of Addis Ababa University, Addis Ababa University.

Cohen, L.,Lawrence,M. And Keith, M.(200) Research In Education. New York: Nowrence Manion and Keith Morrison.

Creswell John,W.(2009)Research Design. 3rd Ed. Usa: Sage Publications.

Day,C.(1999)Developingteachers:Thechallengesoflifelonglearning:London: Flamers.

Dornyei, Z.(2007) Research Methods In Applied Linguistics: Quantitative, Qualitative and Mixed Methodologies. Oxford: Oxford University Press.

Elliot,J.(1999)Action Research For Educational Change. London: Open University press.

Elliot, J. (1991) Action Research for Educational Change. Buckingham: open University Press.

Ernest,P.(1994) An Introduction To Research Methodology And Paradigms. Exeter: University of Exeter Research Support Unit.Fdr Ministry of education (1994) The Ethiopian Education And Training Policy: Addis Ababa.

Ferrrance,E(2000)Action Research. Northeast And Islands regional Educational Institute.

Greenwoo, D. And Morten, L. (1998) Introduction to Action Research. London: Sage Publications.

Hopkins, D (1985) A Teacher's Guide To Classroom Research. Open University Press: Philadelphia.

Koul,L.(1996).Methodology of Educational Research. New Delhi; Vikas Publishing House Pvt. Ltd.

Leh, A.S.C. (2002) Action Research On The Changing Roles Of The Instructors And The Learners. Techtrends, 46 (5), 44-47.

Lioren, M. B. (1994) Action Research: Are Teachers Finding Their Voice? The Elementary School Journal, 95 (1), 3-10.

Mcniff, J. (1988)Action Research: Principles And Practice. London: Routledge.

Mcniff, J. And Whitehead, J. (2002) Action Research: Principles And Practice (2nd Ed)London:Rutledgefalmer. Mcniff, J. And Whitehead, J. (2006) Action Research For Teachers. London: Fulton.

Mcniff, J Lomaxl, P. And Whitehead, J. (2003) You And Your Action Research Project.(2nd Ed).London:Routledgzefalmer.

Menon, S. Usha And C.Almelul.(2011) "Role Of Reflective Teaching In The Evolution Of An Effective Teacher. ’Mjal.Vol.3, No.2, Pp.78-85.

Minstryofeducation.November(2008)General Education Quality Improvement Package (Geqip). Addis Ababa.

Noffke, S. (1994) Practically Critical: An Invitation To Action Research In Education. New York: Teachers College Press, Columbia University.

SeyumTeferra. (1998) "The Current Status Of Research Activities Among Addis Ababa Senior High School Teachers." The Ethiopian Journal of Education, Vol. Xviii/1.

Stenhouse,L.(1975) An Introduction To Curriculum Research And Development. London: Heinemann.

TeshomeNegatebeb. (2006) Action Research in Primary Schools In Ethiopia. Addis Ababa, Academy For Educational Development: Alem Printing Press.

Tran ThiThuhien ,(2009) Why Is Action Research Suitable For Education? Vnu, Journal Of Science. Foreign 
Languages. 25 (2009) 97-106.

Webb, G. (1996). Understanding Staff Development. Buckingham: Open UniversityPress.

Yamane,Tare(1967) Statistics; An Introductory Analysis, $2^{\text {nd }}$ edition,New York: Harper And Row.

YalewEndawok. (2000) "Research Activities, Problems And Future Directions: An Investigation Of Elementary And Secondary School Teachers In Educational Research," In Amare Asgedom, Derebssa Duferra, And Zenebe Barake (Eds.). Proceedings of National Conference Held In Nazereth, March 10-11, 2000. Institute of Educational Research: Addis Ababa University. 